\title{
PENERAPAN DISCRETE DAUBECHIS WAVELET TRANSFORM DALAM WATERMARKING CITRA DIGITAL
}

\author{
Hermawan Syahputra*1, Andani D $\mathrm{N}^{2}$ \\ 1,2 Jurusan Matematika, FMIPA Unimed, Medan, Indonesia \\ e-mail: *1'hsyahputra@gmail.com, ${ }^{2}$ andanidwi19@gmail.com
}

\begin{abstract}
Abstrak
Pelanggaran terhadap Hak Atas Kekayaan Intelektual (HAKI) semakin tinggi. Jadi diperlukan suatu cara untuk menunjukkan pesan rahasia sebagai label kepemilikan. Penelitian ini bertujuan untuk menyisipkan pesan rahasia sebagai bukti otentik berupa logo atau teks ke dalam citra digital menggunakan Discrete Daubechies Wavelet Transform. Penyisipan dilakukan dengan menggunakan teknik watermarking dengan cara penyembunyian pesan rahasia (watermark) atau penyisipan informasi tertentu ke dalam suatu media, tetapi tidak diketahui kehadirannya oleh indra manusia dan mampu menghadapi proses pengolahan sinyal digital. Watermarking dilakukan dengan menyisipkan pesan rahasia (watermark) pada hasil dekomposisi DWT 3-level pada subband lowpass baris dan lowpass kolom (LL). Berdasarkan hasil pengujian, proses penyisipan dan ektraksi watermark dengan menggu-nakan variasi ukuran citra dan format citra, serta penggunaan watermark dan kunci dapat menghasilkan citra ber-watermark sebagai hasil proses penyisipan watermark yang tidak berbeda jauh dengan citra asalnya dengan nilai PSNR di atas 40 dB. Proses watermarking dengan menggunakan DWT mampu bertahan terhadap gangguan rotation dan penambahan brightness and contrast dengan rata-rata nilai PSNR di atas $30 \mathrm{~dB}$.
\end{abstract}

Keywords : Discrete Daubechies Wavelet Transform (DWT), Watermarking, Citra Digital, 3-level DWT, PSNR.

\section{Pendahuluan}

Perkembangan internet yang semakin canggih sangat membawa kemajuan yang semakin berarti dalam berbagai aspek terutama bagi negara yang berkembang. Perkembangan tersebut mengambil peranan penting dalam hal distribusi file digital berupa citra/gambar, audio, maupun video melalui internet. Kemudahan distribusi file digital melalui internet tidak sepenuhnya memberi dampak yang positif. Semakin berkembang dan populernya internet menyebabkan semakin tinggi pula pelanggaran-pelanggaran terhadap hak cipta karya digital [1]. Selama ini pelanggaran atas file digital tersebut dilakukan secara bebas dan leluasa. Pemegang hak cipta atas file digital tentu dirugikan 
karena tidak adanya royalti dan tidak dapat menunjukkan label kepemilikan atas file digital tersebut. Teknik watermarking dapat dijadikan solusi untuk melindungi media digital sebagai bukti kepemilikan media digital. Teknik digital watermarking diterapkan pada berbagai data digital dengan memanfaatkan kekurangan-kekurangan sistem indera manusia seperti mata dan telinga [2].

Metode DWT memiliki kelebihan dalam hal ketelitian analisis terhadap isyarat transformasi [3]. Sehingga pada penelitian ini digunakan metode Discrete Wavelet Transform (DWT) untuk membangun program watermarking pada citra digital, tepatnya menggunakan Daubichies Wavelet sebagai filter. Proses penyisipan watermark dilakukan berdasarkan Human Visual System dengan obyek berupa citra digital, sehingga diharapkan diperoleh watermark yang tidak kelihatan (invisible watermark). Sedangkan proses pengujian kualitas citra dengan menggunakan Peak Signal-to-Noise Ratio (PSNR). Simulasi watermarking citra digital menggunakan proses yang kompleks karena memiliki dimensi yang besar dan diharapkan fasilitas yang ada pada software MATLAB dapat membantu untuk memvisualisasikan solusi dari permasalahan ini.

\section{Metode Penelitian}

\subsection{Citra Digital}

Citra (image) merupakan fungsi continue dari intensitas cahaya pada bidang dua dimensi. Sumber cahaya menerangi objek, objek memantulkan kembali sebagian berkas cahaya tersebut, pantulan cahaya ini ditangkap oleh alat optik sehingga bayangan objek yang disebut citra tersebut terekam [4]. Sedangkan menurut [2], citra digital dapat diartikan sebagai suatu fungsi dua dimensi, $f(x, y)$ dimana $x$ dan y adalah posisi koordinat piksel dan $\mathrm{f}$ merupakan amplitudo di titik koordinat $(\mathrm{x}, \mathrm{y})$ yang sering disebut intensitas atau tingkat keabuan dari citra pada titik tersebut. Citra digital dapat dikodekan dalam bentuk matriks dimana indeks baris dan kolomnya menyatakan suatu titik pada citra tersebut dan elemen matriksnya (yang disebut sebagai piksel) menyatakan tingkat keabuan pada titik tersebut. Pada Gambar 1 ditampilkan contoh koordinat suatu piksel dari citra digital dengan $\mathrm{x}$ mempresentasikan baris dan y mempresentasikan kolom. 


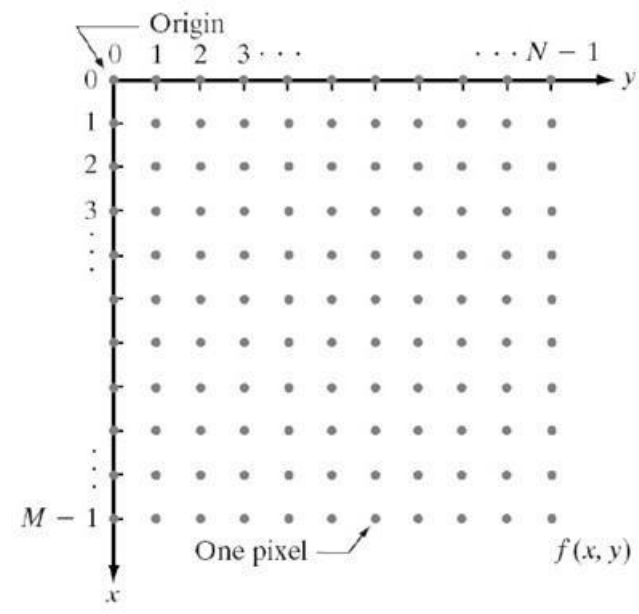

Gambar 1. Contoh koordinat suatu piksel dari citra digital dengan $\mathrm{x}$ mempresentasikan baris dan y mempresentasikan kolom

\subsection{Transformasi Wavelet}

Transformasi wavelet digunakan dalam berbagai aplikasi pemrosesan sinyal, seperti video kompresi, pengenalan obyek, pengolahan citra digital, dan analisis numerik. Secara efisien dapat mewakili beberapa sinyal, terutama yang telah terlokalisasi perubahannya. Pengubahan data dalam bentuk lain agar lebih mudah dianalisis. Transformasi wavelet menghasilkan energi citra yang terkonsentrasi pada sebagian kecil koefisien transformasi dan kelompok lain yang mengandung sedikit energi. Proses trasformasi wavelet dapat dilakukan dengan konvolusi atau proses pererataan dan pengurangan secara berulang. Proses ini banyak digunakan pada proses dekomposisi, deteksi, pengenalan, rekontruksi, dan lainnya yang masih dalam penelitian. Dengan menganalisis sebuah sinyal dengan cara seperti ini akan memberikan informasi tentang kapan dan di mana komponen perbedaan frekuensi [5].

\subsection{Discrete Wavelet Transform (DWT)}

DWT sangat cocok untuk mengidentifikasi daerah tempat dimana watermark disisipkan kedalam citra asli secara efektif. Sifat ini memungkinkan pemanfaatan sistem penglihatan manusia yang lebih peka terhadap perubahan kecerahan dibanding warna [6].

DWT merupakan pentransformasian sinyal diskrit menjadi koefisien-koefisien wavelet yang diperoleh dengan cara menapis sinyal menggunakan dua buah filter yang berlawanan. Kedua tapis yang dimaksud adalah lowpass filter dan highpass filter. lowpass filter mewakili scalling function dengan mengambil citra dengan gradiasi intensitas yang 
halus dan perbedaan intensitas yang tinggi akan dikurangi atau dibuang sehingga gambar menjadi lebih halus. Sedangkan highpass filter mewakili wavelet function dengan mengambil citra dengan gradiasi intensitas yang kasar dan perbedaan intensitas yang rendah akan dikurangi atau dibuang.

Pembagian sinyal menjadi frekuensi tinggi dan frekuensi rendah dalam proses filteralisasi (lowpass filter) dan (highpass filter) disebut dekomposisi. Proses dekomposisi dimulai dengan melewatkan sinyal asal melewati highpass filter dan lowpass filter. Proses dekomposisi ini dapat melalui satu atau lebih tingkatan (level). Dekomposisi satu level ditulis dengan ekspresi matematika pada persamaan 2.2 dan 2.3 di bawah ini:

$$
\begin{aligned}
a_{i} & =\sum_{k} h_{k} s_{2 i+k} \\
c_{i} & =\sum_{k} g_{k} s_{2 i+k}
\end{aligned}
$$

Dimana:

$a_{i}=$ hasil lowpass filter

$c_{i}=$ highpass filter

$s_{2 i+k}=$ sinyal asli

$h_{k}=$ lowpass filter

$g_{k}=$ highpass filter

Pada tahap pertama, sinyal dilewatkan pada rangkaian high pass filter dan low pass filter, kemudian setengah dari masing-masing keluaran diambil sebagai sampel melalui operasi subsampling. Proses ini disebut sebagai proses dekomposisi satu tingkat (level). Keluaran dari low pass filter digunakan sebagai masukan diproses dekomposisi level berikutnya. Proses ini diulang sampai level dekomposisi yang diinginkan. Gabungan dari keluaran-keluaran high pass filter dan low pass yang terakhir, disebut sebagai

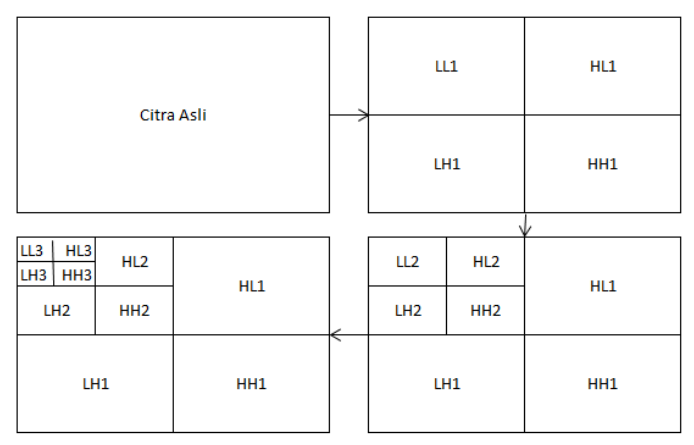

Gambar 2. Hasil Dekomposisi 3-level 
koefisien wavelet, yang berisi informasi sinyal hasil trans-formasi yang telah terkompresi [7]. Sebagai contoh, Gambar 2 adalah hasil dekomposisi 3-level terhadap sebuah citra menggunakan Daubechies Wavelet.

Setelah dekomposisi 1-level, maka akan dihasilkan 4 sub-bands: LL1, LH1, HL1, dan HH1. LL1 tidak diperlihatkan pada Gambar 2. karena langsung didekom-posisikan lagi menjadi LL2, LH2, HL2, dan HH2. LL2 tidak diperlihatkan pada gambar 2.4 karena langsung didekomposisikan lagi menjadi LL3, LH3, HL3, dan HH3. Untuk setiap hasil dekomposisi n-level, LL digunakan untuk dekomposisi n+1-level [8].

Pada transformasi DWT terdapat proses pengembalian kembali komponenkomponen yang telah kita gunakan. Invers Discrete Wavelet Transform (IDWT) merupakan kebalikan dari Discrete Wavelet Transform DWT. Pada transformasi ini dilakukan proses rekonstruksi sinyal, yaitu mengembalikan komponen frekuensi menjadi komponen sinyal semula.

Proses rekonstruksi diawali dengan menggabungkan koefisien DWT hasil dekomposisi. Proses rekonstruksi ini sepenuhnya merupakan kebalikan dari proses dekomposisi sesuai dengan level pada proses dekomposisi [9]. Sehingga persamaan rekonstruksi pada masing-masing level dapat diekspresikan pada persamaan 2.3 sebagai berikut:

$$
s_{2 i}=\sum_{k} h_{k} a_{i}+\sum_{k} g h_{k} c_{i}
$$

\subsection{Watermarking pada Citra Digital}

Watermarking ini memanfaatkan kekurangan-kekurangan sistem indera manusia seperti mata dan teliga. Dengan adanya kekurangan inilah metode watermarking dapat diterapkan pada berbagai media digital. Jadi watermarking merupakan suatu cara untuk penyembunyian atau penanaman informasi tertentu (baik hanya berupa catatan umum maupun rahasia) ke dalam suatu data digital lainnya, tetapi tidak diketahui kehadirannya oleh indera manusia (indera pengli-hatan atau indera pendengaran) dan mampu menghadapi proses pengolahan sinyal digital [10].

Teknik watermarking dapat dikelompokkan menjadi dua kategori yaitu: Domain Spasial dan Domain Transformasi. Domain Spasial lebih mudah pemakaiannya karena tidak menggunakan transformasi, tetapi tidak tahan terhadap serangan. Teknik watermarking menggunakan Domain Transformasi lebih tahan terhadap serangan dibandingkan dengan metode Domain Spasial [11]. 
Salah satu teknik watermarking dalam domain transformasi yaitu metode Discrete Wavelet Transform (DWT). Watermarking yang berbasis wavelet adalah pendekatan yang populer karena kekuatannya melawan standard dan malicious attack.

Citra digital sebelumnya didekomposisi 3-level menggunakan DWT untuk dapat menyisipkan watermark, selanjutnya dijalankan IDWT 3-level untuk merekontruksi citra ber-watermark. Sedangkan proses pendeteksian ada tidaknya watermark dalam citra dilakukan dengan menggunakan pembandingan koefisien yang bersesuaian pada citra berwatermark. Jika koefisien dari rentang frekuensi memiliki nilai PSNR lebih besar dari 30 $\mathrm{dB}$ maka watermark terdeteksi di dalam citra. Inilah proses umum watermarking menggunakan Discrete Wavelet Transform (DWT). Proses ini dipaparkan pada Gambar 2.9:

Secara umum penyisipan watermark dilakukan dengan cara memodifikasi koefisien pada rentang frekuensi LL, LH, HL, atau $\mathrm{HH}$ yang merupakan rentang frekuensi hasil dekomposisi citra menggunakan wavelet. Data watermark ini dapat dianggap sebagai rangkaian bilangan $\mathrm{w}$ dengan panjang $\mathrm{L}$, yang disisipkan pada koefisien rentang frekuensi yang dipilih f. Algoritma umum penyisipan watermark pada koefisien rentang frekuensi diekspresikan pada persamaan 2.4 sebagai berikut:

$$
f^{\prime}=f+\alpha . \omega(k)+K(k), k=1, \ldots, L
$$

Dimana merupakan kekuatan penyisipan yang mengontrol tingkat kekuatan penyisipan watermark dan $\mathrm{f}^{\text {' }}$ adalah koefisien sinyal asal yang telah dimodifikasi, w merupakan watermark yang digunakan. Penyisipan watermark pada citra digital menggunakan DWT ini dilakukan pada koefisien rentang frekuensi (koefisien DWT) sebelum direkonstruksi menggunakan IDWT untuk menjadi citra ber-watermark. Kunci K berguna dalam proses penyisipan watermark sebagai informasi tambahan untuk citra yang disisipi watermark. Pada Aplikasi ini digunakan kunci pada proses watermarking.

\section{Hasil dan Pembahasan}

Hasil pengujian kinerja program dengan menggunakan variasi ukuran citra dan format citra, serta penggunaan watermark berupa image "unimed.jpg" dan kunci (key) "1913" dapat menghasilkan citra ber-watermark sebagai hasil proses penyisipan watermark yang tidak berbeda jauh dengan citra asalnya. Akan tetapi dalam watermarking terdapat cara untuk mengukur tingkat kemiripan antara citra asal dengan citra turunannya yaitu dengan menentukan nilai Peak Signal To Noise Ration (PSNR). Hasil perhitungan PSNR antara citra asal dengan citra hasil penyisipan 
Hasil pengujian kinerja program dengan menggunakan variasi ukuran dan format citra serta penggunaan watermark berupa image "unimed.jpg" dapat menghasilkan citra ber-watermark sebagai hasil proses penyisipan watermark yang tidak berbeda jauh dengan citra asalnya. Akan tetapi dalam watermarking terdapat cara untuk mengukur tingkat kemiripan antara citra asal dengan citra turunannya yaitu dengan menentukan nilai Peak Signal To Noise Ration (PSNR).

Hasil pengujian kinerja program dengan menggunakan variasi ukuran dan format citra, serta penggunaan watermark berupa Teks "Hermawan Syahputra" dan kunci "1913" dapat menghasilkan citra ber-watermark sebagai hasil proses penyisipan watermark yang tidak berbeda jauh dengan citra asalnya. Akan tetapi dalam watermarking terdapat cara untuk mengukur tingkat kemiripan antara citra asal dengan citra turunannya yaitu dengan menentukan nilai Peak Signal To Noise Ration (PSNR). Hasil perhitungan PSNR antara citra asal dengan citra hasil penyisipan.

\section{Kesimpulan}

Berdasarkan hasil penelitian mengenai program aplikasi Penerapan Discrete Daubechies Wavelet Transform dalam Watermarking Citra Digital, maka dapat disimpulkan bahwa:

1. Penerapan Discrete Daubechies Wavelet Transform dalam Watermarking Citra Digital dilakukan dengan menyisipkan pesan rahasia (watermark) pada hasil dekomposisi DWT 3-level pada subband LL. Kemudian gambar direkontruksi melalui proses upsampling dan filtering menggunakan invers highpass dan lowpass filter dari tiap-tiap subband.

2. Penerapan Discrete Daubechies Wavelet Transform dalam Watermarking Citra Digital dibangun dengan menggunakan tampilan GUI (Graphical User Interface) pada Matlab R2009b dapat berjalan dengan baik, dimana proses dekomposisi, penyisipan, dan ekstraksi dapat menampilan hasil sesuai dengan yang diharapkan. Dari implementasi program diperoleh hasil sebagai berikut:

2.1 Watermark yang telah disisipkan pada gambar dapat kembali diperoleh secara baik dan utuh pada proses ekstraksi watermark dengan melakukan proses dekomposisi sebanyak 3-level pada citra ber-watermark.

2.2 Penggunaan kode tidak mempengaruhi kualitas citra ber-watermark, namun penggunaaan kunci dapat memperkecil kemungkinan penyerangan pada citra berwatermark. 
2.3 Jenis file citra digital terbaik didapat dari jenis file yang memberika nilai PSNR tertinggi. Dari kedua jenis file uji yang memberikan, hasil yang terbaik adalah .jpg

3. Berdasarkan pengujian yang dilakukan menunjukkan bahwa:

3.1 Metode watermarking yang digunakan secara umum menghasilkan kualitas citra yang sangat baik. Hal ini ditun-jukkan dari nilai PSNR di atas $40 \mathrm{~dB}$.

3.2 Hasil pengujian kinerja program dengan menggunakan variasi ukuran citra, format citra, penggunaan variasi teknik penyisipan dapat menghasilkan citra berwatermark sebagai hasil proses penyisipan watermark yang tidak berbeda jauh dengan citra asalnya.

3.3 Citra ber-watermark cukup mampu bertahan terhadap gangguan rotation dan penambahan brightness and contrast.

\section{Saran}

Berikut ini beberapa saran bagi para pembaca yang berminat untuk mengembangkan penelitian tentang watermarking menggunakan metode wavelet sebagai berikut:

1. Dekomposisi yang digunakan adalah dekomposisi 3-level. Untuk pengem-bangan selanjutnya dapat digunakan dekomposisi lebih tinggi.

2. Penggujian yang dilakukan hanya standard attack. Untuk pengembangan selanjutnya diharapkan dapat dilakukan penggujian terhadap Mallicious Attack.

3. Dilakukan penerapan Discrete Daubechies Wavelet Transform pada media lain selain citra digital, misalnya pada media teks, audio, video, dan lain-lain.

4. Dilakukan penelitian lebih lanjut terhadap perbandingan teknik water-marking menggunakan metode Discrete Daubechies Wavelet Transform dengan metode lain, sehingga akan diperoleh sebuah metode water-marking yang memiliki kinerja yang lebih baik.

\section{DAFTAR PUSTAKA}

[1] Miller, M. L., (2008): Digital Watermarking and Steganography, Second Edition, Morgan Kaufmann Publishers, United State of America.

[2] Joseph, A., (2013): Robust Watermarking based on DWT SVD, International Journal of Signal and Image Processing, 7(1), 1,2,4.

[3] Ingie, V. K., (1998): Digital Signal Processing Using Matlab, Vol. 4, PWS Publishing Company, Boston.

[4] Sutarno (2010): Analisis Perbandingan Transformasi Wavelet pada Pengenalan 
Citra Wajah, Jurnal Generik, V.

[5] Weeks, M., (2007): Digital Signal Processing Using Matlab, Infinity Science Press LLC, Hingham, Massachusetts.

[6] Xia, X.-G., (1998): Wavelet Transform Based Watermark for Digital Images, Journal University of Delaware, USA, I(I).

[7] Kashyap, N., (2012): Image Watermarking using 2-Level DWT, International Journal of Computer Research, 4(1), 43-44.

[8] Sharma, P., (2013): Digital Image Watermarking Using 3 Level Discrete Wavelet

[9] Alfatwa, D. F., (2013), Watermarking pada Citra Digital Menggunakan Discrete Wavelet Transform, Jurnal Komputasi, ITB, Bandung.

[10] Prawirawan, A., (2011): Implementasi Discrete Wavelet Transform untuk Penyisipan Teks pada Gambar, Journal semanTIK, 1(1), 11-18.

[11] Patrick, L., (2002): Digital Watermarking Using Comple, University Of Cambridge, Cambridge. 
KARISMATIKA

p-ISSN : 2443 - 0366

VOL. 3 NO. 2 AGUSTUS 2017

e-ISSN : 2528 -- 0279 